\title{
Studi Pemberian Bakteri Asam Laktat (BAL) terhadap Persentase Lemak Abdominal dan Berat Karkas Ayam Pedaging yang Diinfeksi E.coli
}

\section{The Effect of Lactic Acid Bacteria (LAB) in Broiler Infected by Escherichia Coli on Abdominal Fat Percentage and Carcass Weight}

\author{
M. R. T. Hutabarat ${ }^{1}$, R. I. Pahlevy ${ }^{1}$, F. Abdurrahman ${ }^{1}$, D. Sibit ${ }^{2}$, W. P. Lokapirnasari ${ }^{3 *}$, K. \\ Soepranianondo ${ }^{3}$, dan Ardianto ${ }^{4}$ \\ ${ }^{1}$ Program Magister, Agribisnis Veteriner, Fakultas Kedokteran Hewan, Universitas Airlangga, Surabaya - \\ Indonesia \\ ${ }^{2}$ PT. Tekad Mandiri Citra, Bandung, Jawa Barat - Indonesia \\ ${ }^{3}$ Departemen Peternakan, Fakultas Kedokteran Hewan, Universitas Airlangga, Surabaya - Indonesia \\ ${ }^{4}$ Departemen Akuntansi, Fakultas Ekonomi dan Bisnis, Universitas Airlangga, Surabaya - Indonesia \\ *Corresponding E-mail: widyaparamitalokapirnasari@gmail.com
}

(Diterima: 23 Agustus 2019; Disetujui: 20 November 2019)

\begin{abstract}
ABSTRAK
Penelitian bertujuan untuk mengetahui pengaruh pemberian bakteri asam laktat (BAL) pada ayam pedaging yang diinfeksi Escherichia coli. Eksperimen ini menggunakan enam spesies bakteri (Lactobacillus casei, Lactobacillus acidophilus, Lactobacillus fermentum, Lactobacillus plantarum, Pediococcus sp. dan Bifidobacterium sp.). Tiga puluh ayam pedaging (Cobb) dibagi dalam 3 kelompok perlakuan, yaitu; kontrol, pemberian probiotik $10^{6} \mathrm{CFU} / \mathrm{ml}$ dan $10^{8} \mathrm{CFU} / \mathrm{ml}$. Jangka waktu studi dilakukan selama 34 hari. Data dianalisis menggunakan one way $\operatorname{ANOVA}(\alpha=0,05)$ dan contribution margin. Hasil penelitian menunjukkan bahwa pemberian probiotik bakteri $10^{8} \mathrm{CFU} / \mathrm{ml}$ pada ayam pedaging yang diinfeksi Escherichia coli menurunkan persentase lemak abdominal sebesar $40 \%$ dibanding dengan kelompok kontrol. Pemberian probiotik tidak dapat meningkatkan berat karkas. Analisis contribution margin menunjukan bahwa jumlah populasi ayam berbanding lurus dengan keuntungan yang dihasilkan.
\end{abstract}

Kata kunci: ayam pedaging, bakteri asam laktat, berat karkas, persentase lemak abdominal, probiotik

\section{ABSTRACT}

TThis study aimed to evaluate the effect of lactic acid bacteria (Lactobacillus casei, Lactobacillus acidophilus, Lactobacillus fermentum, Lactobacillus plantarum, Pediococcus sp., Bifidobacterium sp.) in broiler which is infected by Escherichia coli. This work was conducted at PT. Tekad Mandiri Citra, Bandung, during one period from March to April 2019. A total number of 30 birds (Cobb) divided into the control group, $106 \mathrm{CFU} / \mathrm{ml}, 108 \mathrm{CFU} / \mathrm{ml}$ each group was used 10 birds. Carcass weight and abdominal fat percentage were being analyzed with One Way ANOVA $(\alpha=0,05)$ and margin contribution. The results showed a significant effect $(p<0.05)$ on the abdominal fat percentage from the groups that given $1 \mathrm{ml} / \mathrm{L}$ (108 CFU/ml) of probiotic. The results indicated that the addition of probiotic to broiler diet caused higher improvement in broilers contribution margin value than group control which given diet without probiotic (reduce up to $40 \%$ compared with the control group).

Keywords: broiler, carcass weight, lactic acid bacteria, percentage of abdominal fat, probiotic 


\section{PENDAHULUAN}

Kegiatan budidaya ayam pedaging dihadapkan pada kendala risiko produksi yang relatif tinggi karena rentan terhadap penyakit salah satunya ialah kolibasilosis yang disebabkan bakteri patogen yakni Avian Pathogenic Escherichia coli. Penurunan produksi yang disebabkan kolibasilosis cukup mengkhawatirkan. Hal tersebut dinyatakan dengan tingginya angka mortalitas pada ayam yang terinfeksi. Mayoritas strain Escherichia coli adalah non patogenik yang merupakan mikroflora normal pada usus hewan, namun beberapa diantara galur tersebut bersifat patogenik. Sementara strain Escherichia coli patogenik yang dikenal dengan Avian Pathogenic Escherichia coli (APEC) dapat menginfeksi unggas yang bersifat sistemik dan menimbulkan bakteriemia (Huff et al., 2006).

Berbagai upaya dilakukan untuk meminimalisir perkembangan Escherichia coli patogen dengan pemberian antibiotik, akan tetapi pemakaian obat-obatan tersebut menyebabkan residu antibiotik pada organ dan resistensi bakteri sehingga kemampuan obat untuk mengatasi penyakit menjadi rendah. Bakteri Avian Pathogenic Escherichia coli memiliki kemampuan adaptasi yang baik terhadap obat-obatan sehingga penggunaan antibiotik secara terus-menerus, seperti enrofloxacin, oxytetracycline, dan sulfadimethoxine meskipun berdasarkan dosis yang ditentukan tidak berpengaruh terhadap patogenisitas Avian Pathogenic Escherichia coli. Hal itu terjadi karena ada penurunan kemampuan antibiotik tersebut sehingga menyebabkan resistensi (Glisson et al., 2004).

Probiotik didefiniskan sebagai organisme hidup maupun substansi tidak hidup yang memberikan keuntungan pada keseimbangan mikroba intestinal (Hill et al., 2014). Probiotik telah banyak diteliti sebagai feed-additive menggantikan fungsi antibiotik sebagai growth-promotor. Berbeda dengan antibiotik, probiotik merupakan mikroorganisme yang dapat meningkatkan pertumbuhan dan efisiensi pakan ternak tanpa mengakibatkan terjadinya proses penyerapan komponen probiotik dalam tubuh ternak, sehingga tidak terdapat residu dan tidak terjadinya mutasi pada ternak (Lahtinen et al., 2012).

Sebagian besar mikroba yang digunakan sebagai probiotik merupakan bakteri non patogen. Contoh bakteri yang digunakan sebagai probiotik adalah dari spesies Lactobacillus (Mookiah et al., 2014), Bifidobacterium (Khaksar et al., 2012 dan Pedroso et al., 2013) dan Enterococcus (Mountzouris etal., 2010). Mikrobanon bakteri yang digunakan sebagai probiotik diantaranya Aspergillus oryzae (Daskiran et al., 2012 and Shim et al., 2012), Candida pintolopesii, Saccharomyces bourlardii (Rahman et al., 2013) dan Saccharomyces cerevisiae (Bai et al., 2013). Mikroba probiotik dipilih dengan sifat non patogen, kemampuan bertahan pada kondisi dengan $\mathrm{pH}$ rendah dan konsentrasi garam empedu yang tinggi (Collado and Sanz, 2006). Substrat yang digunakan dalam fermentasi probiotik seperti molase, ekstrak yeast dan pepton, whey, dan pati (Altaf et al., 2006). Selama proses fermentasi berlangsung guna menjaga kestabilan $\mathrm{pH}$ maka dilakukan penambahan buffer (Muller et al., 2009).

Beberapa jalur mekanisme kerja probiotik antara lain pencegahan dan pengontrolan populasi agen patogen enterik (Hung et al., 2012), peningkatan performa ternak, peningkatan penyerapan nutrisi dalam sistem pencernaan (Chawla et al., 2013), produksi substansi antimikroba (Hassan et al., 2012), immunomodulator (Lodemann, 2010) atau stimulasi atau penekanan respon imun (Borchers et al., 2009).

Bakteri asam laktat mensekresikan asam laktat sebagai produk hasil fermentasi karbohidrat. Hasil fermentasi karbohidrat pada organ pencernaan akan meningkatkan kecernaan pakan dan berkorelasi terhadap pembakaran lemak (Stackebrande and Teuberm, 1988). Sebagai hasil dari tingkat kecernaan pakan yang baik maka akan berpengaruh terhadap berat karkas akhir. 
Beberapa genus bakteri asam laktat yang telah terbukti dapat memberikan keuntungan bagi kesehatanyakniLactobacillussp., Pediococcus $s p$., Lactococcus sp., Bifidobacterium sp., Leuconostoc sp., Streptococcus sp (Holzapfel and Wood, 2014).

Karkas merupakan indikator utama keberhasilan suatu peternakan ayam pedaging. Karkas menjadi tolak ukur perbandingan antara modal yang diberikan dalam pemeliharaan ternak dengan daging yang dihasilkan. Jumlah lemak total turut berpengaruh terhadap nilai ekonomis dari karkas, semakin sedikit lemak yang terdapat pada karkas maka semakin tinggi daging yang dihasilkan (Omar, 2014).

Berdasarkan latar belakang tersebut maka pada penelitian ini dilakukan penambahan probiotik bakteri asam laktat pada ayam pedaging yang diinfeksi dengan bakteri Escherichia coli, dengan pengamatan terhadap persentase berat lemak abdominal dan berat karkas akhir beserta analisis contribution margin.

\section{MATERI}

\section{Kelayakan Etik}

Penelitian dilaksanakan setelah mendapat persetujuan Keterangan Kelaikan Etik (Ethical Clearance) dari Komisi Etik Penelitian, Universitas Brawijaya No. 1116-KEP-UB.

\section{Lokasi dan Waktu Penelitian}

Penelitian ini dilaksanakan pada bulan Maret sampai dengan April 2019 di Laboratorium Mikrobiologi (Departemen R\&D I) PT. Tekad Mandiri Citra, Bandung, Jawa Barat. Penelitian tersebut meliputi perbanyakan bakteri Escherichia coli, perbanyakan probiotik bakteri asam laktat, pemeliharaan hewan coba, pelaksanaan penimbangan berat lemak abdominal dan berat karkas akhir.

\section{Bahan dan Instrumen Penelitian}

Bahan yang digunakan dalam penelitian ini adalah hewan coba ayam pedaging (Gallus gallus domesticus) dipelihara mulai umur satu hari dengan berat badan minimal $42 \mathrm{~g}$, probiotik bakteri asam laktat dengan konsentrasi $10^{6} \mathrm{CFU} / \mathrm{ml}$ dan $10^{8} \mathrm{CFU} / \mathrm{ml}$, bakteri Escherichia coli dengan konsentrasi $10^{6} \mathrm{CFU} / \mathrm{ml}$ dosis $1 \mathrm{ml} / \mathrm{kg} \mathrm{BB}$, media natrium agar (NA), media eosin methylene blue agar (EMBA), media de Man Rogosa and Sharpe agar (MRSA) dan de Man Rogosa and Sharpe broth (MRSB), pakan komersial (tanpa antibiotik), alkohol 70\%, kapas, aquades, air. Ayam pedaging berasal dari PT. Tekad Mandiri Citra galur Cobb.

Peralatan yang digunakan dalam penelitian ini antara lain kandang ayam ukuran $1 \mathrm{~m} \times 1 \mathrm{~m} \times 1 \mathrm{~m}$, spuit $1 \mathrm{ml}$, spuit 3 $\mathrm{ml}$, needle $30 \mathrm{G}$, tabung reaksi $15 \mathrm{ml}$, petri disc, ose, spiritus, pembakar bunsen, mesin setrifugasi, korek api, inkubator, pinset, glove, masker, pot organ, klip plastik, objek glass, vaccutainer, ice box, ice pack, sprayer, wadah pakan, wadah minum, pengaduk, timbangan, freezer, gelas ukur.

\section{Hewan Eksperimental}

Seminggu sebelum ayam datang, kandang diberi desinfektan forcent 500 gram dilarutkan dalam formalin 1 liter. Jenis penelitian ini adalah penelitian true experimental, post test only control group design. Rancangan yang digunakan dalam penelitian ini adalah Rancangan Acak Lengkap (RAL). Ayam pedaging sebanyak 30 ekor diacak ke dalam tiga perlakuan (P0, P1 dan P2) pada masing-masing kelompok dengan sepuluh kali ulangan. Hewan coba dibagi menjadi tiga kelompok yaitu:

P0:Ayam pedaging yang diinfeksi Escherichia coli, diberi pakan dan air minum tanpa pemberian probiotik (kontrol positif, sakit).

P1:Ayam pedaging yang diinfeksi Escherichia coli dan diberi probiotik bakteri asam lakat $10^{8} \mathrm{CFU} / \mathrm{ml}$.

P2: Ayam pedaging yang diinfeksi Escherichia coli dan diberi probiotik bakteri asam laktat $10^{6} \mathrm{CFU} / \mathrm{ml}$. 
Ayam dikandangkan dalam kandang tertutup yang dilengkapi dengan instrumen sirkulasi udara, wadah pakan dan air agar dapat dilakukan evaluasi konsumsi pakan dan air. Kandang ayam terbuat dari sekat triplek yang berada dalam ruangan tertutup guna menghindari faktor lain yang dapat mempengaruhi hasil penelitian. Ayam pedaging mulai dipelihara pada umur satu hari atau day old chicken (DOC) dengan waktu adaptasi satu minggu. Ayam pedaging mulai diberi perlakuan pada umur 7 hari dan dipelihara selama lima minggu sampai berumur 34 hari.

Setiap orang yang akan masuk dalam kandang harus menggunakan pakaian dan alas kaki khusus dan terlebih dahulu disemprot menggunakan desinfektan. Pengecekan kesehatan, pembersihan dan pengecekan kotoran, pemeriksaan sisa pakan dan minum, pengukuran suhu dan kelembaban dilakukan setiap hari. Tempat pakan dan minum dibersihkan secara rutin setiap hari. Desinfeksi kandang, peralatan serta penggantian sekam dilakukan seminggu sekali.

\section{Tahapan Penelitian}

\section{Persiapan Probiotik}

Probiotik yang diberikan pada ayam berasal dari biakan murni bakteri asam laktat yang hak paten oleh PT. Tekad Mandiri Citra, yang terdiri dari Lactobacillus casei, Lactobacillus acidophilus, Lactobacillus fermentum, Lactobacillus plantarum, Pediococcus sp., Bifidobacterium sp., yang ditambahkan dengan molase 2\%. Sebelum probiotik bakteri asam laktat diberikan pada ayam dilakukan tahapan uji meliputi: uji McFarland, spektrofotometer dan Total Plate Count (TPC) untuk memastikan bahwa konsentrasi yang diberikan telah sesuai. Pembuatan larutan probiotik dilakukan pada awal pemeliharaan dan disimpan dikulkas untuk menjaga agar konsentrasi probiotik tidak mengalami perubahan.

Isolasi dan Pengujian Bakteri Escherichia coli

Bakteri Escherichia coli didapatkan dari isolat ayam yang didiagnosa mengalami kolibasilosis kemudian dilakukan isolasi lanjutan (uji Indole, motilitas, IMVIC, Simon Sitrat). Infeksi Escherichia coli ditambahkan sebelum pemberian probiotik, induksi dilakukan 1 kali pemberian pada saat usia ayam 14 hari dengan konsentrasi $10^{6} \mathrm{CFU} / \mathrm{ml}$ sebanyak $1 \mathrm{ml} / \mathrm{kg} \mathrm{BB}$ dan diamati gejala klinis selama 3 hari. Perhitungan berat badan awal dilakukan pada saat ayam usia sehari sebelum dilakukan perlakuan. Berat badan akhir dan karkas dihitung setelah ayam berusia 34 hari.

\section{Tahapan Pemberian Pakan}

Ayam pedaging diberi pakan komersil tanpa antibiotic growth promoter dan minum dua kali sehari yakni pukul 09.00 WIB dan 16.00 WIB. Pakan diberikan dengan jumlah yang sesuai dengan kebutuhan nutrisi harian ayam pedaging dalam bentuk pelet dan air minum diberikan secara ad libitum.

\section{Tahapan Cara Pemberian Probiotik}

Tata cara pemberian probiotik melalui minum yakni, sebanyak $1 \mathrm{ml}$ (P1 dan P2) probiotik dilarutkan dalam $1000 \mathrm{ml}$ air (bebas chlorine dan desinfektan lainnya), air diaduk hingga merata. Larutan probiotik tersebut diberikan pada wadah minum pada kelompok perlakuan P1 dan P2 saja. Konsentrasi probiotik yang diberikan pada ayam adalah $10^{6} \mathrm{CFU} / \mathrm{ml}$ dan $10^{8} \mathrm{CFU} / \mathrm{ml}$.

\section{Analisa Data}

Data hasil eksperimen terhadap persentase lemak abdominal dan berat karkas yang didapat dianalisis statistik menggunakan Analysis of Variance (ANOVA) untuk mengetahui apakah terdapat perbedaan yang nyata dari perlakuan yang diberikan. Apabila diperoleh hasil yang berbeda atau berbeda sangat nyata maka dilanjutkan dengan uji jarak berganda Duncan (Kusriningrum, 2008). Analisis statistik menggunakan program SPSS for Windows 23.0. Analisis ekonomi dilakukan dengan menggunakan perhitungan terhadap contribution margin. 


\section{HASIL DAN PEMBAHASAN}

\section{Efek Pemberian Probiotik Bakteri Asam Laktat Terhadap Persentase Lemak Abdominal Ayam Pedaging}

Persentase lemak abdominal merupakan perbandingan antara jumlah lemak dengan berat hidup dan dikalikan $100 \%$. Data hasil olah statistik persentase lemak abdominal pada setiap perlakuan terdapat dalam Tabel 1. Data hasil olah statistik tersebut menunjukkan adanya perbedaan nyata yang terdapat pada kelompok perlakuan yang diberi probiotik bakteri asam laktat $10^{8} \mathrm{CFU} / \mathrm{ml}$ dengan kelompok perlakuan yang diberi probiotik bakteri asam laktat $10^{6} \mathrm{CFU} / \mathrm{ml}$ dan kelompok kontrol $(\mathrm{p}<0,05)$.

Probiotik akan bekerja sama dalam menurunkan kadar lemak dalam tubuh ayam. Probiotik menghasilkan enzim Bile Salt Hydrolise (BSH) yang dapat mendekonjugasi garam empedu. Mekanisme penurunan kolesterol oleh aktivitas BAL disebabkan oleh enzim Bile Salt Hydrolase (BSH) yang mendekonjugasi garam empedu, di mana glisin atau taurin dipisahkan dari steroid sehingga menghasilkan garam empedu bebas atau terdekonjugasi. Enzim BSH menghasilkan garam empedu terdekonjugasi dalam bentuk asam kolat bebas yang kurang diserap oleh usus halus. Dengan demikian, garam empedu yang kembali ke hati selama sirkulasi enterohepatik menjadi berkurang sehingga total kolesterol dalam tubuh menjadi berkurang. Bile Salt Hydrolase dimiliki oleh beberapa strain bakteri saluran pencernaan seperti: Lactobacillus, Enterococcus, Bifidobacterium, Clostridium, Peptostreptococcus, dan Bacteroides (Surono, 2004). Probiotik juga mampu mensintesis enzim esterase bersamaan dengan enzim lipase yang merubah asam lemak bebas menjadi bentuk ester yang berbeda dari trigliserida pada saluran pencernaan (Mahdavi et al., 2005). Selain itu, probiotik bisa menurunkan trigliserida karena kemampuannya memfermentasikan karbohidrat dan menghasilkan asam lemak rantai pendek dalam saluran pencernaan karena sebagaimana diketahui bahwa salah satu penyebab meningkatnya trigliserida bila pakan harian mengandung karbohidrat yang berlebihan (Ljung et al., 2005).

Pemberian probiotik pada ayam menurunkan lemak abdominal dan menurunkan trigliserida karena probiotik secara efektif bisa menurunkan aktivitas acetyl coenzim A carboxylase yaitu enzim yang berperan dalam laju sintesis asam

Tabel 1. Nilai rata-rata dan simpangan baku persentase lemak abdominal ayam pedaging

\begin{tabular}{cccc}
\hline Perlakuan & $\begin{array}{c}\text { Berat Hidup Akhir } \\
(\mathrm{g}) \pm \mathrm{SD}\end{array}$ & $\begin{array}{c}\text { Berat Lemak Abdominal } \\
(\mathrm{g}) \pm \mathrm{SD}\end{array}$ & $\begin{array}{c}\text { Persentase Berat Lemak } \\
\text { Abdominal } \\
(\%) \pm \mathrm{SD}\end{array}$ \\
\hline P0 & $2205,60 \pm 136,99$ & $44,50^{\mathrm{b}} \pm 2,63$ & $2,03^{\mathrm{b}} \pm 0,19$ \\
P1 & $2391,40 \pm 302,99$ & $38,90^{\mathrm{a}} \pm 4,90$ & $1,63^{\mathrm{a}} \pm 0,19$ \\
P2 & $2192,90 \pm 229,37$ & $44,00^{\mathrm{b}} \pm 2,62$ & $2,03^{\mathrm{b}} \pm 0,24$ \\
\hline
\end{tabular}

Keterangan: Notasi (superscript) yang berbeda pada kolom yang sama menunjukkan terdapat perberdaan nyata $(\mathrm{p}<0,05)$

Tabel 2. Nilai rata-rata dan simpangan baku persentase karkas ayam pedaging

\begin{tabular}{ccc}
\hline Perlakuan & $\begin{array}{c}\text { Berat Hidup Akhir } \\
(\mathrm{g}) \pm \mathrm{SD}\end{array}$ & $\begin{array}{c}\text { Berat Karkas } \\
(\mathrm{g}) \pm \mathrm{SD}\end{array}$ \\
\hline P0 & $2205,60 \pm 136,99$ & $1634,10 \pm 148,76$ \\
P1 & $2391,40 \pm 302,99$ & $1796,80 \pm 247,29$ \\
P2 & $2192,90 \pm 229,37$ & $1713,50 \pm 13,53$ \\
\hline
\end{tabular}


JPI Vol. 22 (1): 21-28

Tabel 3. Perhitungan contribution margin skala eksperimen

\begin{tabular}{cccc}
\hline Perlakuan & Penerimaan $(\mathrm{Rp})$ & Biaya Variabel $(\mathrm{Rp})$ & CM $(\mathrm{Rp})$ \\
\hline P0 & 396.900 & 306.000 & 90.900 \\
P1 & 430.380 & 308.500 & 121.880 \\
P2 & 394.740 & 308.500 & 86.240 \\
\hline
\end{tabular}

lemak. Menurunnya kadar trigliserida juga disebabkan oleh meningkatnya populasi dari bakteri asam laktat dalam saluran pencernaan (Santoso et al., 1995).

\section{Efek Pemberian Probiotik Bakteri Asam Laktat Terhadap Berat Karkas Ayam Pedaging}

Karkas merupakan indikator ekonomi keberhasilan suatu usaha peternakan ayam pedaging. Karkas yang baik memiliki nilai yang mendekati dengan standar berat badan harian. Pertambahan berat badan harian dipengaruhi oleh beberapa faktor seperti galur, jenis kelamin, jenis pakan, jenis kandang dan keadaan lingkungan sekitar. Pada penelitian ini ayam yang digunakan adalah ayam galur Cobb, oleh sebab itu acuan pemeliharaan memperhatikan panduan standar yang telah ada.

Berat karkas adalah hasil yang diperoleh dari penimbangan berat ayam setelah dikurangkan dengan bulu, darah, kepala, leher, jerohan dan kedua kaki. Persentase berat karkas diperoleh dari perbandingan nilai berat karkas dengan berat hidup dan dikalikan $100 \%$. Data hasil olah statistik berat karkas pada setiap perlakuan terdapat pada Tabel 2 berikut ini. Berdasarkan data hasil olah statistik menggunakan ANOVA dengan uji lanjutan Duncan, diketahui tidak terdapat perbedaan yang nyata antar kelompok perlakuan dengan pemberian probiotik $10^{8} \mathrm{CFU} / \mathrm{ml}$, kelompok perlakuan pemberian probiotik $10^{6} \mathrm{CFU} / \mathrm{ml}$ dan kelompok kontrol $(\mathrm{p}>0,05)$.

Analisis Usaha Pemberian Probiotik Bakteri Asam Laktat Pada Ayam Pedaging

Contribution Margin (CM). Indikator keuangan yang digunakan dalam analisis usaha ayam pedaging dalam skala penelitan ini adalah dengan menggunakan perhitungan contribution margin. Rumus perhitungan contribution margin adalah sebagai berikut:

\section{Contribution Margin (Margin Kontribusi) $=$ Penerimaan - Biaya Variabel}

Contribution margin merupakan proyeksi kontribusi keuntungan terhadap suatu unit usaha. Nilai contribution margin pada setiap perlakuan tercantum dalam Tabel 3.

\section{KESIMPULAN}

Berdasarkan penelitian yang telah dilakukan maka dapat disimpulkan bahwa pemberian probiotik bakteri asam laktat $\left(10^{8} \mathrm{CFU} / \mathrm{ml}\right)$ dapat menurunkan persentase lemak abdominal pada ayam pedaging yang diinfeksi dengan Escherichia coli dan tidak menghasilkan pertambahan berat karkas pada ayam pedaging yang diinfeksi dengan Escherichia coli. Nilai keuntungan dan contribution margin pada pemeliharaan ayam pedaging skala eksperimen menunjukkan bahwa keuntungan terbesar terdapat pada kelompok perlakuan yang diberi probiotik bakteri asam laktat $\left(10^{8} \mathrm{CFU} / \mathrm{ml}\right)$.

\section{UCAPAN TERIMA KASIH}

Penulis mengucapkan terima kasih kepada Prof. Dr. Koesnoto Soepranianondo sebagai pembimbing utama sehingga penelitian dapat selesai hingga tuntas, kepada segenap jajaran direksi PT. Tekad Mandiri Citra, Bandung yang telah memfasilitasi penelitian, dan kepada Universitas Airlangga yang telah mendukung penulis dalam penyelesaian penelitian. 


\section{DAFTAR PUSTAKA}

Altaf, M., Naveena, B., Venkateshwar, M., Kumar, E. V. and Reddy, G. 2006. Single step fermentation of starch to $\mathrm{L}(+)$ lactic acid by Lactobacillus amylophilus GV6 in SSF using inexpensive nitrogen sources to replace peptone and yeast extract-optimization by RSM. Process Biochemistry, 41(2): 465-472.

Bai, S., Wu, A., Ding, X., Lei, Y., Bai, J., Zhang, K. and Chio, J. 2013. Effects of probiotic-supplemented diets on growth performance and intestinal immune characteristics of broiler chickens. Poultry Sci. 92(3): 663-670.

Borchers, A.T., Selmi, C., Meyers, F.J., Keen, C. L. and Gershwin, M. E. 2009. Probiotics and immunity. Journal of Gastroenterology, 44(1): 26-46.

Chawla, S., Katoch, S., Sharma, K. and Sharma, V. 2013. Biological response of broiler supplemented with varying dose of direct fed microbial. Veterinary World, 6(8): 521-524.

Collado, M.C. and Sanz, Y. 2006. Method for direct selection of potentially probiotic Bifidobacterium strains from human feces based on their acid-adaptation ability. Journal of Microbiological Methods, 66(3): 560-563.

Daskiran, M., Onol, A. G., Cengiz, O., Unsal, H., Turkyilmaz, S., Tatli, O. dan Sevim, O. 2012. Influence of dietary probiotic inclusion on growth performance, blood parameters, and intestinal microflora of male broiler chickens exposed to posthatch holding time. Journal of Applied Poultry Research, 21(3): 612-622.

FAO. 2016. Probiotics in Animal Nutrition. Animal Production and Health. Food and Agriculture Organization of The United Nations. Rome.

Glisson, J. R., C. L. Hofacre, and G. F. Mathis. 2004. Comparative efficacy of enrofloxacin, oxytetracycline, and sulfadimethoxine for the control of morbidity and mortality caused by Escherichia coli in broiler chickens. Avian Dis. 48(3): 658-662.

Hassan, M., Kjos, M., Nes, I., Diep, D. and Lotfipour, F. 2012. Natural antimicrobial peptides from bacteria: characteristics and potential applications to fight against antibiotic resistance. Journal of Applied Microbiology, 113(4): 723736.

Hill, C., Guarner, F., Reid, G., Gibson, G. R., Merenstein, D. J., Pot, B., Morelli, L., Canani, R. B., Flint, H. J. dan Salminen, S. 2014. Expert consensus document: The International Scientific Association for Probiotics and Prebiotics consensus statement on the scope and appropriate use of the term probiotic. Nat. Rev. Gastroenterol. Hepatol. 11(8): 506514.

Holzapfel , W. H. and Wood, B. J. 2014. Lactic Acid Bacteria Biodiversity and Taxonomy. Oxford: Wiley Blackwell.

Huff, G. R., W. E. Huff, N. C. Rath, and G. Tellez. 2006. Limited treatment with $\beta$-1,3/1,6-glucan improves production values of broiler chickens challenged with Escherichia coli. Poult. Sci. 85:613-618.

Hung, A. T., Lin, S.-Y., Yang, T.-Y., Chou, C.-K., Liu, H.-C., Lu, J.-J., Wang, B., Chen, S.-Y. and Lien, T.-F. 2012. Effects of Bacillus coagulans ATCC 7050 on growth performance, intestinal morphology, and microflora composition in broiler chickens. Animal Production Science, 52(9): 874-879.

Lahtinen, S., Ouwehand, A.C., Salminen, S. and Wright, A.V. 2012. Lactic Acid Bacteria Microbiological and Function Aspects. London: CRC Press.

Lodemann, U. 2010. Effects of Probiotics on Intestinal Transport and Epithelial Barrier Function. pp. 303 et seq. in: Bioactive Foods in Promoting Health: 
Probiotics and Prebiotics. Academic Press, Waltham, USA.

Khaksar, V., Golian, A. and Kermanshahi, H. 2012. Immune response and ileal microflora in broilers fed wheat-based diet with or without enzyme Endofeed $\mathrm{W}$ and supplementation of thyme essential oil or probiotic PrimaLac. African Journal of Biotechnology, 11(81): 14716-14723.

Mookiah, S., Sieo, C. C., Ramasamy, K., Abdullah, N. and Ho, Y. W. 2014. Effects of dietary prebiotics, probiotic and synbiotics on performance, caecal bacterial populations and caecal fermentation concentrations of broiler chickens. Journal of the Science of Food and Agriculture, 94(2): 341348.

Mountzouris, K., Tsitrsikos, P., Palamidi, I., Arvaniti, A., Mohnl, M., Schatzmayr, G. and Fegeros, K. 2010. Effects of probiotic inclusion levels in broiler nutrition on growth performance, nutrient digestibility, plasma immunoglobulins, and cecal microflora composition. Poultry Science, 89(1): $58-67$.

Muller, J. A., Ross, R. P., Fitzgerald, G. F. and Stanton, C. 2009. Manufacture of probiotic bacteria. pp. 725-759, in: D. Charalampopoulos and R.A. Rastall (eds.). Prebiotics and probiotics science and technology. Vol. 2. New York: Springer Science and Business Media.

Omar, M. A. E. 2014. Economic evaluation of probiotic (lactobacillus acidophilus) using in different broiler breeds within egypt. Benha Veterinary Medical Journal (24) 2: 52-60.

Rahman, M., Mustari, A., Salauddin, M. and Rahman, M. 2013. Effects of probiotics and enzymes on growth performance and haematobiochemical parameters in broilers. Journal of the Bangladesh Agricultural University, 11(1): 111118.

Stackebrande.T and Teuberm. 1988. Molecular taxonomy and phylogenetic position of lactic acid bacteria, Biochimie 70:317324.

Vuyst, L. D. and Vandamme, E. J. 1994. Bacteriocins of Lactic Acid Bacteria Microbiology, Genetics and Applications. New York: Springer Science and Business Media. 